\title{
ANTONIA MERCÉ "LA ARGENTINA" EN MÉXICO
}

\author{
Alberto Dallal
}

\section{Trayectoria de Antonia Mercé}

No es seguro que Antonia Mercé haya nacido en 1888 (algunos señalan que el año de 1890); sí que su arribo a este planeta haya ocurrido en Buenos Aires - de aquí el sobrenombre-, de padres españoles, bailarines profesionales y siempre de viaje; Manuel Mercé (andaluz) y Josefina Luque (castellana). La niña estudió ballet, con ellos, desde los cuatro años de edad. A los once había sido escogida como "primera" en la Ópera de Madrid pero a los catorce la inquieta mujer había abandonado el escenario de la danza clásica para estudiar las danzas autóctonas y regionales de España. A esa edad, su madre (ahora viuda), se erigió en su única profesora de danza y se concentró en capacitar a Antonia en las distintas modalidades de una danza española que, hasta esas fechas, había evolucionado espontáneamente, llena de vigor y vitalidad, en piezas religiosas, folklóricas, populares, que guardaban sus propias reglas de improvisación y que, comparadas con las danzas escénicas y de concierto, según los entendidos resultaban "bruscas, incluso brutales, carentes de plasticidad". ${ }^{1}$ La decisión de Antonia, hasta esas fechas bailarina de ballet - concentrarse en el arte de la danza española- resulta comprensible en su trayectoria; desde pequeña descubre, afina, asienta, convive con las cualidades de una serie de modalidades que, por siglos, había permanecido vigente como propiedad exclusiva de la gente del pueblo; detecta la singularidad y la pureza de obras, actitudes y rutinas que habían alimentado otros niveles del arte de la danza - por ejemplo, el mismo ballet-y que, en su caso había contemplado como expresión y solaz directos de los asiduos de los tablados y escenarios populares. El "arrebato" de Antonia Mercé no resulta incomprensible; tampoco inesperado si se considera que, como indica Levinson,

${ }^{1} D E, 18$ 
... la técnica de un bailarín no es como los engranajes mecánicos de un muñeco abisagrado; se trata de un esfuerzo físico constantemente alimentado de belleza. Esta técnica no es el esfuerzo suplementario de su arte, no es un mero ardid, diseñado para ganarse un aplauso fácil, tal como ocurre (según Stendhal) en el arte del versificador espontáneo. La técnica constituye el alma misma de la danza; es la danza. ${ }^{2}$

Si posee la técnica, el bailarín se percatará de los llamamientos que -fibras en su interior- lo inclinan a preferir no sólo la ejecución o la recreación, sino la misma creación de tipos de danzas más cercanas a su ser interior, su nacionalidad, su cultura, su idiosincrasia, las características de su biografia.

El ejecutante de las danzas populares -folklóricas o urbanas- posee una técnica forjada como rutina de adiestramiento y de acoplamiento con coreografías que en ocasiones van trasladándose de generación en generación. El ejercicio cotidiano del bailarín o bailarina de las danzas populares - teatrales o no teatrales - implica — aun sin aparente método- la preparación ineludible del cuerpo para el desarrollo y la realización de las piezas, de las obras, los lapsos - como en la ópera, la opereta y la zarzuela-y los prolongados espectáculos de danza.

Por otra parte, sabemos que las rudezas y disciplinas de la técnica clásica han forjado, preparado, dado pie a muchos cuerpos que, alejados de la danza clásica teatral, de concierto, quedan aposentados en distintos campos del espectáculo, ya sea en el teatro ligero o frívolo, ya sea en las modalidades nacionales que constantemente completan y se anexan a la danza clásica o se desarrollan paralelamente a ella. Anna Pávlova explicaba cómo

... además de los numerosos, variados y complicados pasos que pertenecen al ballet clásico, la bailarina tiene que aprender a ejecutar ciertas danzas nacionales e históricas: el minuet, la mazurka, danzas húngaras, italianas, españolas etcétera. ${ }^{3}$

Muchas de estas piezas regionales o nacionales completan los grandes espectáculos de la danza clásica: las coreografias de gran envergadura. En ellas es posible detectar la inclinación de coreógrafos y ejecutantes por incorporar secuencias, actitudes, pasos, trazos y vestimentas locales a las historias, más o menos fantasiosas y complicadas, de los grandes ballets.

El estilo y el repertorio que forjó Antonia Mercé a partir de sus apren-

${ }^{2} D T A, 114$

${ }^{3} N P D, 8(2 \mathbf{a}, \mathrm{p})$ 
dizajes y sus investigaciones no fueron recibidos, al principio, sino en cafés, cabarets y teatros de revista pero al terminar la primera guerra mundial fue ovacionada en el Moulin Rouge de París. Tras de callados e infructuosos intentos de divulgar su arte - Enrique Granados le había descubierto y casi gritaba, hasta su muerte, en marzo de 1916, sus excelencias- viene Antonia a ser proclamada, en 1928, la más o por lo menos, una de las más grandes bailarinas de danza española de todos los tiempos. En sus indagaciones, Antonia Mercé había descubierto, dentro de las formas bruscas, rudas, brutales, directas y elementales de algunas danzas españolas, las vetas sublimes, intensas, significativas, expresivas de una gama enorme de trazos, secuencias, rutinas e improvisaciones. Antonia Mercé aminoró, afinó los efectos de su arte. Decantó evoluciones. Asimismo percibió y asimiló las más delicadas secuencias, dotándolas de una concentración profesional proveniente tanto de su sensibilidad como de sus estudios. En algunas de sus coreografías conservó el ataque seco y preciso pero lo hizo exacto, dancísticamente seguro. En alguna pieza "moldeó" aspectos femeninos y destacó gestos y movimientos de brazos y manos descubriendo sus roles u objetivos técnicos. Diseñó vestuarios apoyándose en los atuendos originales, subrayando aquellos detalles que permitían a los espectadores regodearse en las "líneas de acción" dancísticas. Alguien percibió que Antonia Mercé "La Argentina" recuperaba un arte que por siglos había estado en manos - en pies y cuerpos- de gitanos errantes, de razas y nacionalidades temperamentales, ubicado en el centro mismo de una gran cultura, obsesionado por la mezcla y el desplazamiento peninsulares.

El arte de Antonia Mercé "La Argentina" respondía simultáneamente a una necesidad interna, personal, y a un prurito de conservar en las obras de repertorio, el espíritu y la trayectoria histórica de las danzas originales. Al respecto, a "La Argentina" le costaba trabajo expresar su ideario o, mejor, su credo:

Me es difícil -decía- estar en calma cuando se trata del baile. Quisiera tanto que me comprendieran, que se sintiera todo lo que yo siento tan ardientemente y que realizaran la satisfacción pura y simple que da a aquellos que le aman. Hay en él tanto de misterio... En España él expresa todo: es un rezo en ciertas danzas religiosas, un llamado arrebato en otras que inspiran guerras o revueltas. Hay un baile para festejar una buena cosecha y éste es comprendido por todos, pero hay otros que al contrario brotan cuando la cosecha ha sido mala. ${ }^{4}$

\footnotetext{
${ }^{4}$ Antonia Merce "La Argentina", "Bailar es vivir", $R R, 2$ de febrero de 1936.
} 
Después de estudiar con sus padres, ambos bailarines españoles, Antonia viene a ser, a los once años, bailarina principal del cuerpo de la Ópera de Madrid; en 1923, dueña ya de su propio repertorio, se presenta en París, primero en el Teatro Olimpia y poco después en el Fémina, durante ciertas "matinées espagnoles". Pero su reconocimiento como gran bailarina se ensancha a medida que el público se percata de la síntesis que logra, técnica y coreográficamente, de la danza española, habilidad y talento que quedarán comprobados en El amor brujo, de Manuel de Falla, estrenado en la Ópera de París en 1928. Durante los ocho años siguientes, "La Argentina" vive las intensidades del triunfo pero también los esfuerzos del arte verdadero: sus actuaciones son exhaustivas, totales, y el fenómeno mismo -arte y autenticidad - habrá de acabar con ella. Al preguntársele, en 1934, cuáles eran algunas de sus grandes emociones, contestó:

Así de pronto no sabría decírselo, ya que son varias las que se dan de trompadas en mi memoria. Sin embargo, tal vez pudiera ser la que sentí el mes de mayo pasado, al ovacionarme el público de Madrid después de haber bailado El amor brujo. A Aquello fue un delirio de entusiasmo! Otra muy intensa fue cuando el gobierno francés me condecoró con la Legión de Honor ${ }^{5}$

\section{La danza española}

Como la fiesta brava - los toros-y las procesiones, la danza española no es fácilmente ubicable dentro del sistema de costumbres y estructuras culturales. Aunque considerada globalmente la danza española puede calificarse como una de las más finas y originales del mundo, sus antecedentes y las vías de desenvolvimiento posteriores a veces resultan contradictorias con esta calificación. Las buscadas intensidades y arrebatos dinámico-espaciales dentro de las ejecuciones indican un culto a la violencia e incluso a lo grotesco. El taconeo, práctica común en varias regiones de España, representa asimismo una habilidad: la creación simultánea de la música que ha de acompañar a las ejecuciones —original destreza que comparte este tipo de danza española con el $i a p$ norteamericano y con las danzas autóctonas de tipo prehispánico- . Con respecto a otras modalidades europeas de danza regional, autóctona o incluso folklórica, la danza española resulta más pura, emocional y, a la vez, severa. En la España actual existen prácticas cuya génesis data de la supremacía helenística en

${ }^{5} \mathrm{CCU}, \mathbf{8 5}$ 
el Mediterráneo (alrededor del año 550 antes de Cristo) y ya en el cenit del Imperio romano se hablaba de ciertas bailarinas andaluzas, originarias de Cádiz, que viajaban a lugares lejanos para causar las delicias de múltiples y variados grupos de espectadores.

La invasión de los árabes marcó definitivamente las danzas practicadas en la Península. Las hizo más fuertes, incorporó vocalizaciones como acompañamientos y vigorizó el manejo de brazos, cintura, dedos y el arqueo de la espalda. La mayor influencia artístico-dancística fue ejercida por los moros en Andalucía y hasta la fecha se confunden los significados de los términos danza española y danzas andaluzas o danzas de Andalucía.

Los árabes mantuvieron su tradición de considerar las ejecuciones y las prácticas de música y de danza como prerrogativas reales. Los califas "entretenían" a sus invitados y familiares con estas artes. Apenas iniciada la liberación política y la recuperación del territorio, los reyes Isabel y Fernando dieron un gran impulso a las formas literarias populares y al teatro español; este último anexó los ejercicios y las piezas dancísticas a su renacimiento y consagración. En Sevilla y en Toledo, la iglesia aceptó a la danza como una forma de aglutinamiento y cohesión sociales. Entre las modalidades más socorridas por la realeza española de esta época se cuentan la sarabanda, la pavana y el pasacalle. Antes de dos siglos, sin embargo, las formas dancísticas españolas se habían multiplicado y expandido popularmente. Los ritmos musicales se desenvolvieron con rapidez y eficacia paralelamente a los pasos y las secuencias dancísticas. Brotaron y se desarrollaron el fandango, el bolero, la cachucha, las seguidillas manchegas. De estas últimas surgen las sevillanas, modalidad considerada hasta la fecha como danza nacional de España. Las distintas regiones del país dieron lugar y nombre a variadas formas de danza y el hábito de llamar a cada modalidad según su sitio de origen fue trasladado a la América española automática y fructíferamente.

De manera general, y estableciendo dentro del mismo marco de referencia los distintos géneros dancísticos surgidos y desarrollados en España a lo largo de cinco siglos, algunos estudiosos han dividido la producción de danza española en cuatro grandes rangos o "estilos": 1) danzas regionales, 2) el flamenco, 3) la "escuela" o danza de escuela y 4) el renacimiento español Según La Meri, las coreografias pertenecientes a las danzas regionales resultan de índole variada gracias a que utilizan tanto solos como duetos, corros, danzas grupales y danzas circulares. Es un grupo de modalidades dancísticas fino, espontáneo, a veces muy elaborado según las distintas influencias sociales, históricas y étnicas. Son las piezas que algu- 
nos grandes exponentes de la danza española han trasladado al escenario con éxito sorprendente. El flamenco, por su parte, posee un arranque original, distinto de las demás modalidades o estilos de la danza española. Surgió en el sur de España, en el medio de los gitanos. Algunos etnólogos ubican su aparición en los territorios de la India, tesis casi corroborada por las crónicas persas. Sin embargo, los antecedentes hindúes (gitanos) y moros se confunden o se imbrican en el verdadero flamenco, algunos de cuyos ritmos y modalidades coreográficas resultan difíciles de ejecutar por gente que no pertenezca a las "tribus" de ciudades españolas como Granada o Sevilla. Mencionaremos, como "platillos fuertes" de toda cuadrilla flamenca auténtica, las alegrías, los soleares, las bulerías, la farruca, el zapateado, el tango (flamenco) y la zambra.

La "escuela" o danza de escuela se refiere a las instituciones que brotaron espontáneamente en España durante los siglos XVIII y XIX, lapso en el que se desarrollan las modalidades "urbanas" en el ámbito paralelo de la fiesta, la celebración civil y religiosa y el escenario popular. También sirve como punto de ubicación en su paso al tratamiento "balletístico" de la música y de la danza popular española. Como antecedente o modelo se menciona el caso del bolero, modalidad que, según la tradición o la leyenda, asimiló Cerezo, maestro y bailarín de la corte francesa, para lograr más vistosas presentaciones a partir de 1780 . Las "escuelas" surgidas a partir del flamenco (seguidillas, malagueña, etcétera) nutrieron una enorme cantidad de vetas, estilos y piezas de la danza popular pero también de la danza clásica teatral.

Marius Petipa, el gran coreógrafo, por años, siendo joven, apoyó su entrenamiento en la danza española; incluso bailó "el fandango en la algarabía de una feria en San Lucas. Su experiencia en España" fundamentó su capacidad para desempeñarse en papeles de carácter, en danzas estrambóticas y en los divertissements de Carmen o de Don Quijote. ${ }^{6}$ Por su parte, Leonide Massine resulta el "descubrimiento juvenil" de Dighilev, entre otras cosas, gracias a su versatilidad y su capacidad de adaptación para absorber "la rica escuela del género clásico original de la Península ibérica. [Con el tiempo] Massine llega a dominar la escuela española como pocos españoles lo hacen...."

El renacimiento de la danza española, al comenzar el siglo XX, logró dos importantes victorias: primero, el reconocimiento de la danza española como una modalidad original, dueña de sus propios espacios, intérpre-

${ }^{6} D A N, 256$
${ }^{7} D A N, 295$ 
tes, reglas y trayectorias, incluyendo las técnicas apropiadas para desempeñarlas y, segundo, la incorporación de la danza española a la gran danza teatral de concierto. Aunque hay antecesores espléndidos, poco estudiados, la máxima figura del "renacimiento" de la danza española es Antonia Mercé "La Argentina", toda vez que su genialidad o excepcionalidad entremezcló conocimiento, investigación, sencillez en la expresión, sabiduría en la re-construcción, sensibilidad en la renovación y pasión por el género. "Fue la primera en establecer la antigua escuela, las técnicas tradicionales de España en [el contexto de] las composiciones clásicas de Albéniz, de De Falla, Turina y otros grandes compositores. ${ }^{8}$

\section{Imposición de un arte verdadero}

La primera visita de Antonia Mercé "La Argentina" a México, en 1917, adquiere especial significación si se considera que la fama de la bailarina, en Nueva York - capital de los espectáculos de danza a partir de los años treinta-, no queda reconocida sino hasta 1928, no obstante que la bailarina se había presentado en 1916. Su debut en Nueva York fue inesperado y hasta accidentado. Ocurrió de la siguiente manera: en enero de $1916 \mathrm{el}$ Metropolitan Opera House invitó al compositor Enrique Granados a presenciar el estreno mundial de su ópera Goyescas. Antes de viajar a los Estados Unidos, Granados cablegrafió a Buenos Aires -en donde se hallaba Antonia - para que la bailarina española actuara en el papel principal. Cuando ambos llegaron Rosina Galli ya había sido contratada para lo mismo, razón por la cual Antonia Mercé sólo pudo presentarse -con ausencia del público y críticos-durante una matinée en un teatro de segunda clase. En 1919 había actuado nuevamente en Nueva York - con los mismos raquíticos resultados-, en una extravaganza musical española de Valverde titulada La tierra de la felicidad. No fue hasta noviembre de 1928 cuando obtuvo el éxito que se merecía. Se presentó en seis recitales con su propio repertorio y fue proclamada como la más grande bailarina española de todos los tiempos. ${ }^{9}$

Cuando Antonia Mercé visitó México por primera vez, en 1917, tenía 29 años de edad. Sus actuaciones sorprendieron a tiros y troyanos - público y crítica一, no obstante el enorme arraigo y la proliferación que la danza española tenía - y tiene- en el país, fenómeno que hacía al mexi-

\footnotetext{
${ }^{8} D E, 447$.

${ }^{9} D E, 17-18$.
} 
cano un público exigente y aguzado. La relación de los hechos de "La Argentina" apareció de la siguiente manera según el criterio de un desconocido cronista de la revista Pegaso:

El viernes de la semana pasada debutó en el teatro Colón una verdadera maravilla que se hace llamar "La Argentina". Ya la empresa nos habia dado a conocer algunas opiniones europeas y suramericanas y supusimos desde luego que "La Argentina" levantaría entusiasmos en la crítica mexicana, pero a fuer de ser sinçeros, diremos que jamás llegamos a pensar que la bailarina en cuestión habría de hacer violencia sobre nuestra expresión modesta, para obligarnos a exaltarla.... "La Argentina" presenta bailes españoles depurándolos de todo lo canallesco y vulgar para elevarlos a un nivel estético. No es una bailadora de jotas y boleros; es algo más, es una artista y una artista en un arte raro y prodigiosamente bello.

En México se aman todas las formas de la danza española. Se practican muchas. Desde la época de la Colonia, la aclimatación de las danzas populares se realizó de manera paulatina, inexorable; algunas modalidades curiosas e inusitadas adquieren una suficiente independencia expresiva que las convierte en aportaciones mexicanas. En los bailes mestizos la danza española prolonga sus afanes de celebración colectiva y en algunos casos se afina; en otros apoya o da pie a formas completamente nuevas. No eran gratuitas, por tanto, estas exaltadas afirmaciones.

"La Argentina" ha estabilizado los bailes españoles y los ha presentado ante la cultura francesa, belga y norteamericana, consiguiendo de todos los críticos el premio que se le merece. "La Argentina" tiene conciencia exacta de los valores estéticos dentro del baile y practica el culto del ritmo y del movimiento, tomando un poco de los bailes clásicos y otro poco de los bailes españoles para hacer algo exóticamente personal. "La Argentina" es una mezcla de Salomé y una maja de Goya. Esbelta y elegante, se mueve en la escena con tanto decoro y gentileza que se confunde a momentos con la luz del reflector.

La depuración de "La Argentina" no habría producido efectos tan notables si las danzas españolas hubiesen perdido sus elementos fundamentales. El extraordinario temperamento de Antonia había perdurado en sus finas interpretaciones porque la bailarina no violentaba las formas. Sabía que mucho de la danza española había generado, en la técnica clásica, poses, pasos, actitudes; ella logra, mediante percepciones excepcionales, hacer más evidentes la calidad y los trazos que la modalidad ya posee:

¿Y tocando las castañuelas? Nosotros creímos que las castañuelas tendrían en el mundo la misión única de entusiasmar cálidamente las escenas de una feria 


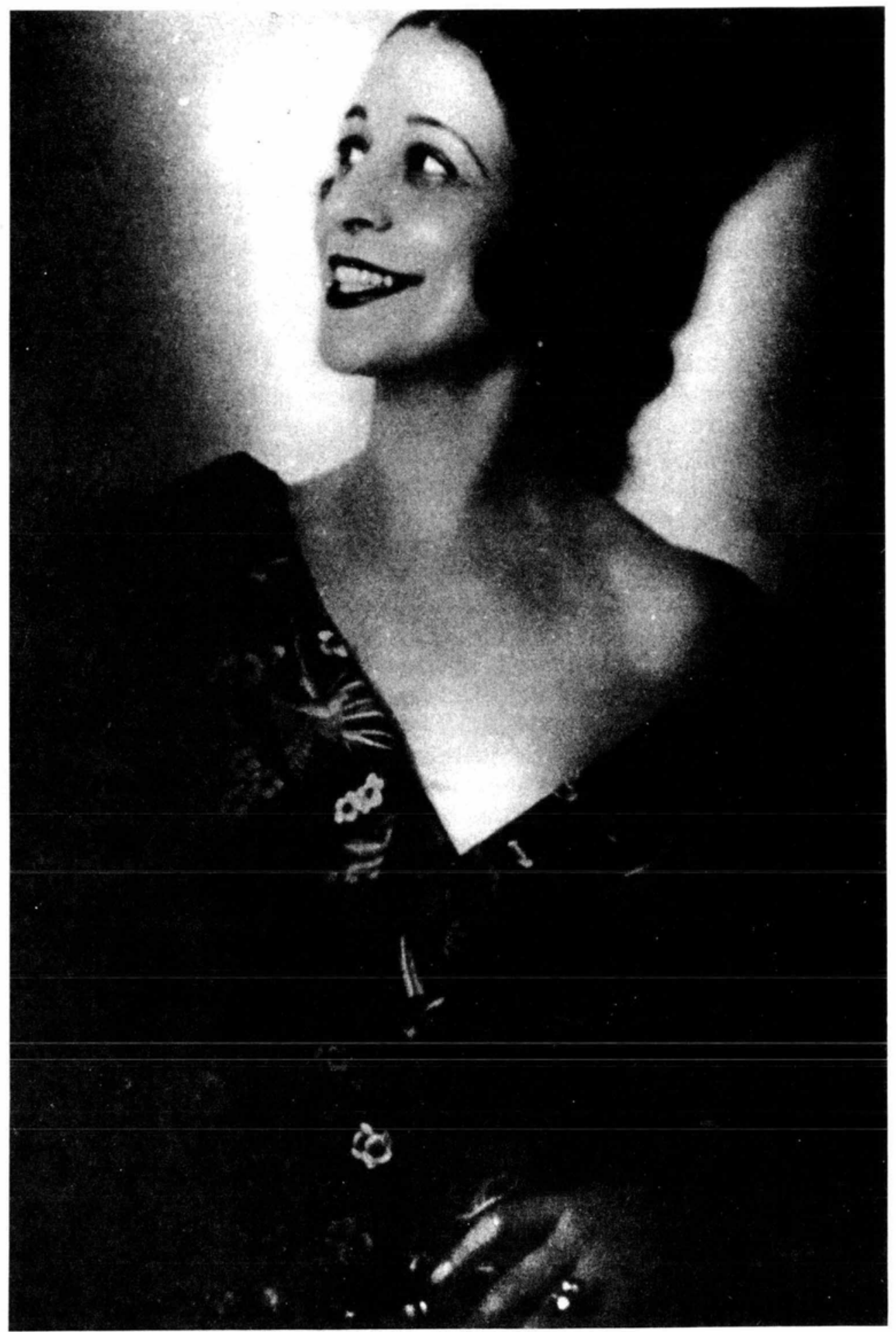

1. La primera visita de Antonia Mercé "La Argentina" a México tuvo una enorme importancia para la carrera de la artista española. 
DOI: http://dx.doi.org/10.22201/iie.18703062e.1990.61.1570

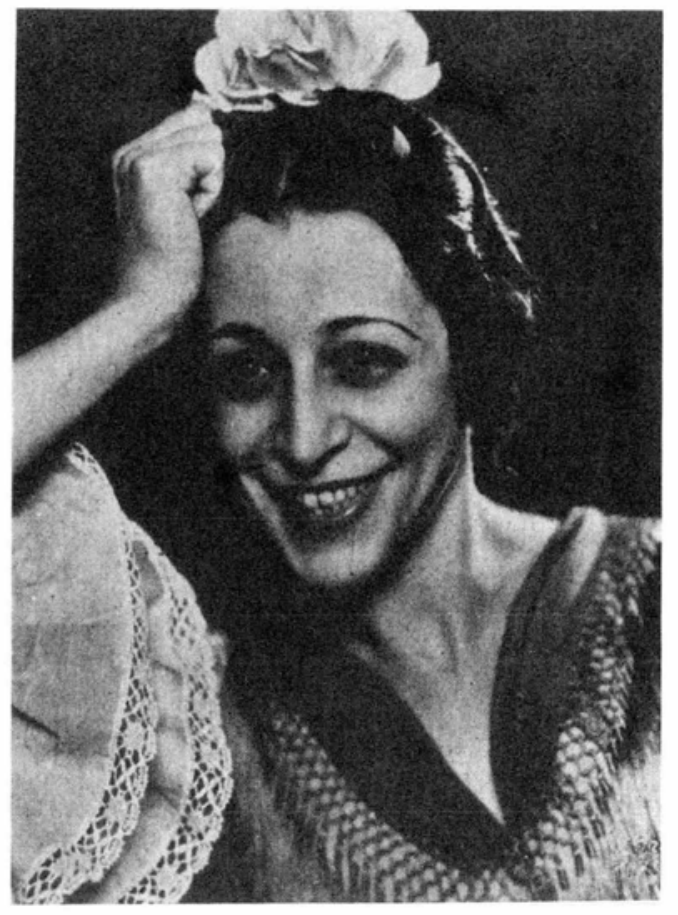

2. La prensa mexicana elogió siempre a Antonia Mercé y alabó su simpatía y accesibilidad.

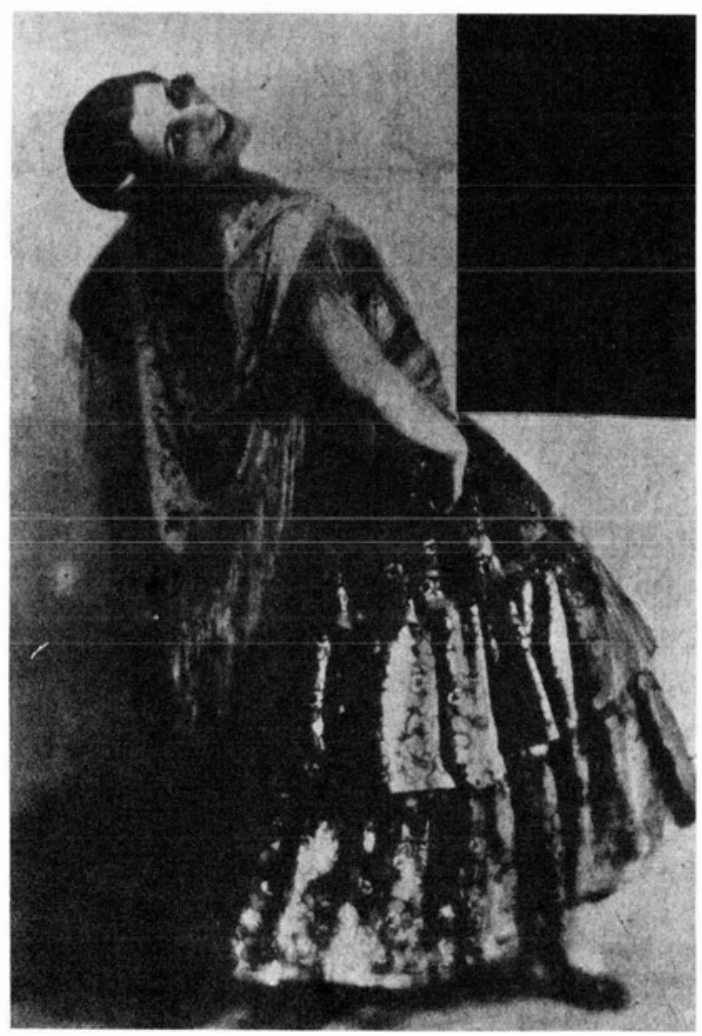

3. Antonia Mercé "La Argentina”. Ilustración a un texto de Revista de Revistas, 1934. 
cualquiera; que estarían destinadas a despertar en los expatriados iberos y en los mexicanos hispanófilos el grito bronco y libertino, pero todo, todo, dentro de una estallante monotonía. "La Argentina" viene revelando que las castañuelas en las manos virtuosas de esta bailarina lloran y se ríen, semejan un clamor de entusiasmo y se adormecen en un secreto amoroso y dulce. Los empresarios del Colón están de plácemes $y$, con toda justicia, ya que pueden vanagloriarse de haber presentado al público un espectáculo extraordinario que agradará a los profanos y a los cultos. ${ }^{10}$

No fallaron las percepciones de cronistas y espectadores y mucho menos de poetas al ver bailar a "La Argentina". La artista había unido espléndidamente la línea popular de la danza española con la coreografía y la ejecución finas que sólo pueden adquirir brillo pleno en la danza teatral, en el escenario.

El grupo de la revista Pegaso aprovechó la excepcionalidad de la gran bailarina española para lanzar un

\section{CONCURSO DE CARICATURAS \\ DE "LA ARGENTINA"}

Los cronistas de la prensa metropolitana y la empresa del Teatro Colón, con objeto de estimular a los caricaturistas residentes en esta capital y aprovechando la visita que nos hace la genial bailarina de fama mundial, Sra. Antonia Mercé de Paz, "La Argentina", ha decidido convocar a un concurso de caricaturas que constituya, a la vez que un impulso para nuestros dibujantes humorísticos, un recuerdo para la admirable artista que tan hondas impresiones estéticas nos deja.

\section{BASES}

I.- El objeto de este concurso es el de premiar las tres mejores caricaturas de "La Argentina" en cualquiera de sus bailes.

II.- Cualquier persona podrá tomar parte en el concurso enviando una o más caricaturas de la referida artista.

III.- Las caricaturas deberán ser de un tamaño mínimum de veinte por treinta centímetros.

IV - Las caricaturas deberán entregarse en la Contaduría del Teatro Colón, dirigidas al Señor Don Alberto Díez, Gerente de la Unión Teatral, S. eñ P. Dichos trabajos deberán enviarse firmados con pseudónimo, y en sobre cerrado, marcado con el mismo pseudónimo el nombre del autor, con su dirección, recabándose en la misma Contaduría el recibo correspondiente a cada trabajo que se envíe

${ }^{10} \mathrm{Pe}, 320$. 
V.- El concurso quedará abierto desde la fecha de esta convocatoria y se cerrará el 30 de junio a las 6 p.m.

VI.- Las caricaturas que se reciban serán exhibidas en los pasillos interiores del Teatro Colón.

VII.- Habrá tres premios para las 3 mejores caricaturas, repartidos en la forma siguiente: primer premio, una medalla de oro con inscripción alusiva y cien pesos oro nacional; segundo premio, una medalla de plata con inscripción alusiva y cincuenta pesos oro nacional; tercer premio, un diploma y veinticinco pesos oro nacional, cuyos premios son ofrecidos por la empresa del teatro Colón.

VIII.- Los trabajos premiados serán obsequiados a "La Argentina" en su función de beneficio, y dicha artista, esa misma noche, entregará en público a los agraciados el premio correspondiente.

IX.- El jurado estará integrado por tres de los más reputados pintores radicados en México y por un crítico de arte, cuyos nombres serán dados a conocer oportunamente.

X.- Tanto las caricaturas premiadas como las demás que a juicio del jurado lo merezcan, serán publicadas en las principales revistas ilustradas de la capital, previo ruego que se hará en ese sentido a los editores de dichas publicaciones.

NOTA.- Además de los premios ofrecidos por la Empresa del Teatro Colón, si hubiese algunos otros que se ofrecieran para este concurso, el jurado queda facultado para otorgarlos en la forma que lo estime conveniente.

La bailarina había desatado una verdadera euforia en México. El fenómeno Antonia Mercé podía seleccionar de la tradición —el tablado, el acto ritual, la tribu - esa intensidad, ese vigor de cuerda punzante que el canto y el baile flamenco ya habían ofrecido por el mundo del folklore y del espectáculo, esos "gitanismos" flamencos, "manguindoys", seguiriyas gitanas que experimentan fama y divulgación internacional y, a la vez, formación consistente y definitiva durante el siglo XVIII.

"Siglo de las luces" también por lo que toca al flamenco, en el XVIII quedan rotos los atávicos empeños que mantenían al cantante en un anonimato casi clandestino, entre religioso y tribal. Es el florecimiento máximo, la culminación del proceso artístico del cante y del baile, junto a los primeros temores de su decadencia, temores que sobrevendrían muy poco después. A lo largo del XVIII, el flamenco se muestra como realidad viva más que como palabra y marca registrada; cobran cuerpo y madurez algunos de sus géneros esenciales y surgen las primeras referencias a cantaores y estilos que han llegado hasta nuestros días: el polo, la caña, la toná, la seguiriya, géneros mencionados en este siglo y en las primeras décadas del siguiente aun por plumas tan alejadas de la investigación folklórica como las de Cadalso, Pastor Díaz..., Espronceda - Valera, a quien una seguiriya todavía famosa le inspiró en 1848 y en Nápoles un soneto; éste es quizá el primer contacto de la poesía culta con el mundo del flamenco y ésta la copla que lo motivó: 


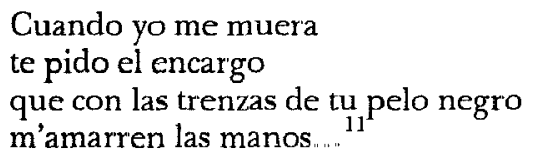

En el número del 29 de junio de 1917 de Pegaso, se registraba el éxito de Antonia:

Colón.- Sigue Antonia Mercé de la Paz privando de entusiasmo a las gentes de buen gusto. En los últimos días ha bailado música de Grieg y de Massenet, sobresaliendo una Danza campesina del primero. Durante esta misma semana irá presentando algunas novedades hasta llegar a bailar la Danza de los siete velos. Toda la intelectualidad de México, toda la gente culta, noche por noche deja en la taquilla una cifra moderada y dentro del teatro, deja "polvo de manos" de tanto aplaudir a la gente danzante.... La empresa del Colón y los cronistas de la prensa metropolitana han organizado un concurso de caricaturas para premiar las tres mejores que se hagan de "La Argentina" en cualquiera de sus bailes...

En la mente y en la sensibilidad de Ramón López Velarde, la actuación de "La Argentina" desatará un sorprendente conjunto de imágenes, excepcionales todas, y en el número 15 de la revista Pegaso, correspondiente al 21 de junio de 1917, el poeta de Zacatecas publicará

\section{LA ESTROFA QUE DANZA}

\section{A Antonia Mercé}

Ya brotas de la escena cual guarismo tornasol, y desfloras el mutismo con los toques undívagos de tu planta certera que fiera se amanera al marcar hechicera los multánimes giros de una sola quimera.

Ya tus ojos entraron al combate como dos uvas de un goloso uvate; bajo tus castañuelas se rinden los destinos, y se cuelgan de ti los sueños masculinos, cual de la cuerda endeble de una lira, los trinos.

Ya te adula la orquesta con servil dejo libidinoso de reptil,

${ }^{11}$ FVM, 140-141. 
y danzando lacónica, tu reojo me plagia, y pisas mi entusiasmo con una cruel magia como estrofa danzante que pisa una hemorragia.

Ya vuelas como un rito por los planos

limítrofes de todos los arcanos; las almas que tu arrullo va limpiando de escoria, quisieran renunciar su futuro y su historia, por dormirse en la tersa amnistia de tu gloria.

Guarismo, cuerda, y ejemplar figura: tu rítmica y eurítmica cintura nos roba a todos nuestra flama pura; y tus talones tránsfugas, que se salen del mundo por la tangente dócil de un celaje profundo, se llevan mis holgorios al azul pudibundo. ${ }^{12}$

El poema, apenas escrito el 14 de junio, tal como lo expone en su versión publicada en Pegaso, registra el pleno impacto producido por la bailarina en el espíritu sensual y abierto del poeta. Octavio Paz ha descubierto con creces el enamoramiento o la fascinación de la poesía de López Velarde con el cuerpo humano.

López Velarde... siente la fascinación de la carne -explica Paz- que es, siempre, fascinación ante la muerte: al ver "el surco que deja en la arena su sexo", el mundo se le vuelve "un enamorado mausoleo". La visión del cuerpo como presencia adorable y condenada a la putrefacción 13

La danza - y sobre todo la danza española — en toda su intensidad y su finura habría de suscitar en López Velarde este sentido sexual, fanático del cuerpo pero tendrá que reconocer en sus versos contundentes la capacidad de la danza para intentar una contrarresta del destino del cuerpo. La certeza de que el cuerpo vibrante de la bailarina hace que desaparezcan las maniobras y las fantasías sexualizadas del espectador, domina al poema. "La Argentina", una vez en el escenario, no sólo es perseguida por las miradas masculinas sino también por las notas y estrofas de la música. Tras ella "se rinden los destinos"; hay una sugerente alusión a los miembros genitales del varón y acaba la artista pisando "una hemorragia". Con todo, en este acto de plena libertad que ejecuta la bailarina, esta mujer excepcional sale del mundo. Y su misión -como la que descubren casi

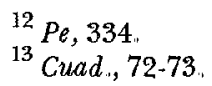


universalmente los espectadores con respecto a la danza- consiste en diluir, llevándoselas, las más excitadas sensaciones; vánse éstas hacia un "azul pudibundo", cielo transfigurado o, mejor, lavado que cae fuera de la realidad que todos los mortales padecemos.

En el mismo número en que aparece el poema del zacatecano, se comenta, ahora con voz más viva, el impacto causado por la presentación de Antonia Mercé. Y ante la intensidad de las frases, se hace posible creer que "La Argentina" había superado todas las expectativas.

"La Argentina", esa libélula-mujer, esa maja inteligente que ha hecho brotar las estrofas de nuestro poeta López Velarde, sigue quitando el juicio a cuantos la miran. Nosotros seguimos afirmando que hasta hoy se ha visto en México un baile español verdaderamente artístico y seguimos afirmando también que para tocar las castañuelas, como las toca "La Argentina", se necesita ser ipor vida de la Duncan!, un Lloyd George y tener un cerebro en cada dedo. Junto a los movimientos rítmicos de "La Argentina", los movimientos de las hojas de las palmas, el roce de la brisa, resultan torpes y ridículos. iMiren ustedes que poner en ridículo a las palmas! $!^{14}$

Comprobamos el arrobo de los lectores cuando el cronista vincula, en una petición, la algarabía de tener en la Ciudad de México a Antonia Mercé con la posibilidad de que sus actuaciones tengan influencia en el mundo dancístico metropolitano y en otro mundo no dancístico:

Dueña del ritmo y del instante preciso: encárgate de las horas que vuelan sobre este México y encáuzalas; encárgate de aligerar a nuestra vista el paso de los dolores y las vanidades; encárgate del movimiento de todas las emociones; encárgate de todo, de todo, para que cuando te alejes quede una estela de precisión, ritmo y encanto en todas las cosas que nos rodean.... Encárgate, siquiera por ocho días, del tráfico urbano.....

Pero es Alejandro Quijano, en el número 17 de Pegaso, el que de manera más "técnica" y cuidadosa descubre y analiza la personalidad artística y las ejecuciones de bailarina. Titula sus comentarios "La picardía honesta":

La palabra "picardia", cuyo significado según los léxicos incluye una actuación deshonesta, ha venido sufriendo un cambio. Y tal, que hoy el título de esta crónica constituye sólo una antimonia aparente. De hecho puede haber picardía sin encallamiento. Así sucede con esta bailarina genial, Antonia Mercé, que

${ }^{14} \mathrm{Pe}, 340$
${ }^{15} \mathrm{Pe}, 340$. 
ha edulcorado, con el encanto bibleo de sus bailes, quince o veinte noches ciudadanas. ${ }^{16}$

En seguida confiesa Quijano el atractivo de imán que ha ejercido la artista sobre su físico, al grado de alterar su pachorrudez y obligarlo a desplazamientos inesperados:

Tres o cuatro veces - y para mi pachorra fogaril es mucho- he encaminado mis pasos al teatro en donde la musa desgrana sus inspiraciones. $Y$ tres o cuatro veces ante el deleite que invade la sala, como si un bosque bíblico vertiera sus aromas en ella, he agradecido a la amistad de Ramón López Velarde las palabras animadoras y descongestionantes que me llevaron por primera vez al dignificado recinto.

En seguida Quijano describe - casi con pelos y señales- a la egregia bailarina, singularizando detalles que, generalmente, no podemos hallar en las "críticas de danza" —o "crónicas", como a veces se les llama-y que obligan a los lectores de años y siglos posteriores a literalmente "ver" a la dama en su imaginación.

Es "La Argentina" una mujer esbelta, de una estilizada simplicidad de líneas poco grata a la burguesía, pero encantadora para la aristocracia del gusto. Tiene, engarzados en el óvalo de la cara, una boca sonreidora en la que, en apretadas hileras, lucen los dientes su magia nívea, y dos ojos magníficos, cuyo deleitoso "reojo plagia"... De un color zarco -como aquellos otros ojos zarcos de Mimí Aguglia, que también supieron un día, sólo un día en que quiso la ilustre sustraerse el fiero destellar de la mirada trágica, hechizarnos en las diabluras coquetas de "Santarelina"- los ojos de Antonia Mercé picardean, picardean siempre en alardes de gracia. Pero esta picardía no es de la "clásica" bailarina de los tablados hispalenses en la que el reír de los ojos, adaptándose luego al atrevido movimiento corpóreo, no siempre estético ni elegante, nos produce una emoción apenas dionisiaca, jamás artística. La mirada de los ojos de esta danzante, correspondiendo a una movilidad ansiosa, llena de ritmo y nervios, de toda la figura, requiere una sonrisa extática más que una ardiente y entusiasta eclosión. El decoro no sufre mengua con esta danza exquisita, y los sentidos, excitados por ella nuevamente, van más al arrobo que al impulso.

Y más adelante, en apretado comentario, Quijano explicaba lo que más le gustaba de "La Argentina":

La flexibilidad maravillosa de su cuerpo, el juego único de los finos brazos, la deleitable mirada, el fresco y amable sonreír, son algo que no debiera pasar tan fugazmente....

${ }^{16} P e, 6$ de julio de 1917 
Por su parte, I. Flores Maciel publicaba un poema dedicado a "La Argentina", también en Pegaso:

\author{
Ya comprendo al sacrílego tetrarca \\ que en su embriaguez de sanguinario artista \\ rompió de sus escrúpulos el arca \\ y entregó la cabeza de Bautista. \\ $\mathrm{Y}$ admiro el gran emperador esteta \\ que se perdió en el fuego de unos ojos, \\ porque puede ir al Accio un rey poeta \\ por un puñado de claveles rojos. \\ Yo no sé si la sueño o si la miro, \\ no sé si estoy despierto o si deliro, \\ porque es tan suave el ritmo de su danza, \\ tan voluptuoso el vuelo de su giro, \\ que parece, al llegar, una esperanza \\ y se aleja después como un suspiro.
}

México, junio de 1917.

La primera noticia que Pegaso da a conocer en torno al concurso que la propia revista había organizado con motivo de la visita de la bailarina española, aparece el 13 de julio de 1917. A la letra informa:

En otro lugar de esta revista publicamos unas copias de las caricaturas que obtuvieron el premio en el concurso abierto por la empresa del Teatro Colón.... El primer lugar correspondió a José Ma. Fernández Urbina y el segundo a Carlos Neve... El concurso estuvo más desairado de lo que podía esperarse dado el entusiasmo que despertó entre nosotros Antonia Mercé... Se presentaron alrededor de treinta caricaturas, pero de ellas solamente valían la pena lass de Urbina, las de Neve y alguna otra. El jurado estuvo con acierto al conceder los premios.

Y para continuar con la avalancha de elogios que la revista había publicado desde que Antonia iniciara sus presentaciones, en el mismo número se publicaba un "Poema inédito" de Efrén Rebolledo alusivo y dedicado a la impresionante bailarina: 


\section{ANTONIA MERCÉ}

Vibran con alborozo

Los crótalos triunfales

Simulando el retozo

Del granizo que hiere los cristales.

$\mathrm{Y}$ al salir del tapiz, la bailarina

Aparece en la escena

Con la irrealidad de una ondina

En la aridez luciente de la arena.

Coruscante Dureola

De su cuerpo, la saya

Si se abre es amapola,

Lirio si se desmaya.

En sus cándidas manos

Los cascabeles negros

Suspiran en los pianos

Cantan en los alegros.

En bulliciosa fiesta

De nevados jazmines

Aunándose a la orquesta

Se agigantan sus chapines.

Y sus brazos de nieve

Que se alzan con gallardía

Son asas de una leve

Ánfora de armonía.

Las suaves castañuelas

Trinan en sus redondas

Falanges como oscuras filomelas

En la paz enlunada de las frondas.

Bailan sus labios rojos

Rasgando sus corolas perfumadas, Y hasta sus verdes ojos

Guiñan un raudo baile de miradas. 
Un espeso tapiz de palmas huella

Su pie, y al dibujar cada postura

Lo mismo que una estrella

Es casta y luminosa su figura.

$Y$, en efecto, en otras páginas de la revista se reproducían las caricaturas ganadoras. En el primer premio, la figura de "La Argentina" lucía un cuello largo, mostrando parte de la espalda. La bailarina mira al "espectador" y sonríe; lleva las castañuelas en las manos. Las caricaturas de Neve, que ilustran el poema de Rebolledo, captan de mejor manera el movimiento que la danzante realiza y logra en el escenario, exagerando, como era de esperarse, poses y "estilos".

A un espectador tan exigente de la danza de calidad como Carlos González Peña -intransigente, habrán de calificarlo algunos- Antonia Mercé le causa imágenes y adjetivaciones que -no por tradicionales en la crítica de la danza- no dejan de contener un hilo de objetividad $y$, sobre, todo, denotan un pensamiento de admiración ante la personalidad de la bailarina.

Muestra de las más elocuentes de artística valía es la persistencia del recuerdo. Se olvida lo que nada dice a nuestro espíritu; lo que pasó sin dejar huella. Leve perfume que se desvanece; melodía sin contorno perdida a poco, silueta que presto se anega en sombra, el artista -aun el que por un momento logró cuativarnos-, no se aposentará por modo definitivo en nuestra memoria, si no acertó a imprimir en ella el sello de una personalidad radiante, única, que nada ni nadie podría borrar... ¿Quién ha olvidado a "La Argentina"?... Vino aquí por primera vez en 1917.... Retornó en 1920... A un embeleso sucedió otro embeleso; la inicial impresión no hizo sino ahondarse y fortalecerse. Después, la hemos seguido en su larga peregrinación por el mundo. Ya entraba en zonas de luz - cuando hasta acá llegaba el cco de sus triunfos-; ya en fugitiva penumbra, cuando de ella ninguna noticia teníamos. Pero siempre, en todo momento, aquel nombre estaba presente en nuestro recuerdo. ${ }^{1}$

Vuelve "La Argentina"

El 21 de abril de 1920 el periódico El Universal anunciaba el debut de Antonia Mercé en el Teatro Colón; iniciaría sus presentaciones el día 30. Se expresaba el periódico de la artista española como de "la bailarina del

${ }^{17} A M, 115$ 
milagro". El Excélsior del 4 de mayo publicaba la crónica de las actuaciones de Antonia:

Noche a noche, la maga del ritmo, la bailarina del milagro, Antoñita Mercé, "La Argentina", es calurosamente aplaudida por el público metropolitano que acude a admirar sus clásicas y sugestivas danzas.

Habíamos escrito la crónica de su debut, que fue un triunfo para la gentil danzarina, pero el exceso de material impidió que se publicara oportunamente; sin embargo, en estas líneas va nuestro aplauso entusiasta para esa artística labor tan llena de elegancia y de gentileza.

$\mathrm{Y}$ en ella hay que admirar, como en una época anterior, ese inimitable manejo de las castañuelas, en lo que es sin rival, y la donosura de sus danzas. Hay una de estas, la habanera de "El hombre es débil" que es un portento de estilización. En el ritmo acendrado del baile, apenas una leve ondulación de la cadera marca el movimiento; ipero cómo se adivina en aquella cintura cimbrante aquella movilidad que hacía famosos a los bailarines gaditanos en los tiempos de los Césares romanos! ${ }^{18}$

Para el 8 de mayo, el Excélsior anuncia a"La Argentina" como "la única en sus bailes" y al día siguiente la cartelera indica que la bailarina ofrecerá "nuevos bailes". Ese mismo día 9, Revista de Revistas publica la reseña de Roberto "El Diablo":

Henos aquí de nuevo hechizados por el milagro eurítmico de Antonia Mercé He aquí que después de una añorada ausencia, la danzarina de "Alegrías" ha vuelto a ofrendarnos el don gentil de su elegancia rítmica. Con la misma sonrisa amiga de nuestros corazones surgió otra vez su grácil silueta en el escenario del Colón, y nuestros espíritus noche a noche han tornado a embriagarse con la escultórica belleza que prodiga en sus danzas amables.

No es este lugar para hacer un estudio de la técnica de la "Argentina" puesto que de sobra conocemos sus cualidades esenciales; su innata elegancia, su espiritual delicadeza, su pulcritud estética. Sus bailes todos tienen serenidades de remanso, poseen una aterciopelada suavidad de caricia que asperja nuestra alma de una recóndita y dulce idealidad. No es una bailarina de friso griego, arrebatada por el vértigo dianisíaco (sic), sino danzarina milagrosamente arrancada de un tapiz versallesco. La "Argentina" es al baile lo que el madrigal a la poesía. Es sensible que pocos estrenos nos haya ofrecido hasta hoy en su repertorio y ellos a fuer de sincero no han sido del agrado del público, pero es fácil escuchar entre los espectadores del Colón frases que así lo atestiguan y por las que expresan sus preferencias a los ya conocidos, el fado por ejemplo. De los bailes nuevos que ha presentado, yo prefiero para mi particular delectación la Habanera de Sarasate, que estiliza de modo admirable. Con qué ponderada

${ }^{18}$ Banedictus: "Entre-Bastidores", Ex, 4 de mayo de 1920 
gracia inhibe apenas surgido el vaivén voluptuoso, resolviéndolo en una leve ondulación del talle que está muy lejos de hacer florecer las sangrientas rosas del deseo. El público metropolitano ha recibido a la "Argentina" en la cordialidad de los viejos amigos que no se olvidan y cuya presencia es una noble satisfacción interior. Yo seguí a través de la prensa la última gira de Antonia Mercé y me place aquí hacer constar que en todas las entrevistas que leí de ella tuvieron siempre sus labios gentilezas para nuestro país.

Vayan pues aquí, al par que mis parabienes por el éxito de su debut, el agradecimiento por su generoso proceder en el extranjero para México (sic). ${ }^{19}$

Sin embargo, la situación política revuelve los ánimos y trastroca los hábitos de los capitalinos. Acosado por las huestes del obregonista general Pablo González, el presidente Carranza ha salido de la Ciudad de México y acaba por caer asesinado en Tlaxcalaltongo el 21 de mayo. Las circunstancias hacen difíciles las habituales salidas a los recintos teatrales, al grado de que los críticos se lamentan de la siguiente manera:

Aunque todos los teatros metropolitanos se hallen ocupados por los espectáculos más diversos, no ha habido en ellos ningún suceso sobresaliente en la semana anterior. "La Argentina" inauguró sus viernes de moda, dedicando la primera de esas funciones a la Prensa de la capital. Como siempre, la espiritual danzarina cautivó con la magia incomparable de su ritmo, con su arte especial y característico a la concurrencia que asistió al espectáculo. Sí debemos lamentar que, siendo como es este espectáculo, de una alta tendencia (sic) y de una belleza intrínseca tan grande, el público se haya mostrado, a últimas fechas, un poco retraído para la gentil bailarina, notándose desconsoladores vacíos en la sala que no há mucho contempláramos llena y entusiasmada." ${ }^{20}$

En esa misma nota aparecían unos bellos apuntes de Ernesto García Cabral inspirados en los bailes de "La Argentina", en los que, mediante rasgos dinámicos y sintéticos, se expresaban los movimientos de la notable española. Por su parte, en El Universal Ilustrado del 20 de mayo S. B. examina el arte de Antonia Mercé de la siguiente manera ("On dirait que c'est une ame qui danse"):

Es difícil analizar los bailes de la señora Mercé, porque no obstante su técnica manifiesta y perceptible, son de tal manera estéticos que embotan toda facultad crítica. Quizás esto se debe al dominio cerebral que posee esta artista sobre todos sus movimientos, encadenando figuras, previamente estudiadas, de una manera tan sencilla y tan lógica que termina por engañar nuestros ojos y nos convierte en seres puramente contemplativos.

Ese insuperable dominio de la danza coloca a la señora Mercé por encima de

19 Roberto "El Diablo": "iSursum corda!", $R R, 9$ de mayo de 1920.

${ }^{20}$ Los Diablos Mayores: "La semana teatral", $R R, 23$ de mayo de 1920 
muchas grandes intérpretes: "Tórtola Valencia", por ejemplo, se deja subyugar por el tema perdiendo la noción exacta de sus acciones. La música y el ritmo enloquecen su inflamable temperamento y se torna en una desenfrenada bacante que se emociona ante el público.

En cambio la "Argentina" nunca pierde su fría cualidad. A los bailes españoles que son cálidos e intensos sabe darles el matiz necesario sin llegar nunca a las exageraciones flamencas. Las "Bellas Chelitas", que van esparciendo por el mundo la España de pandereta no tienen puntos de contacto con esta bailarina un poco cerebral y un mucho española, que desde Rusia hasta México ofrece, en su ritmo, el alma de la España culta.. No hay en Antonia Mercé —cuando interpreta la música roja de Valverde- esa tendencia a la "españolada" que tanto gusta en el género chico, sino que, por el contrario, su interpretación es de un tono violeta, como son los cuadros de Zuloaga, y su baile va mostrando al espectador una España nueva más culta, más artista y carente de toda exageración drolática y de todo aspecto brutal. Hay que verla en "Alegrías" estilizando una corrida de toros, porque entonces la suprema elegancia del toreo, en lo que tiene de arte abstracto, surge al conjuro de la reina de los crótalos y vemos una fiesta brava sin oro, sin sangre, y con un discreto sol de abril...

Además, Antonia Mercé puede interpretar la "Gavota" con la misma sencillez con que danza un baile flamenco, porque ese tono de estos bailes discretos encaja perfectamente en ella que huye de las brusquedades aromáticas y de las exageraciones interpretativas.

En este baile académico la señora Mercé ha logrado lo que nadie pudo hacer hasta hoy Como afirmó un crítico hace tiempo, ella ha podido, con su inteligencia, convertir un baile hecho para dos personas, en una danza para una sola intérprete. Es cierto que vemos, en su "Gavota" al personaje invisible que va de la mano siguiendo la melodía. Es cierto que cada ademán, cada paso de la "Argentina" nos ofrecen al compañero que no podemos ver, pero que "existe".. iHe aquí el talento exquisito de Antonia Mercé, creando un fantoche que danza, cuando menos en espíritu!

Es curioso sentirse espectador de Antonia Mercé en el "Baile flamenco", un torrente de notas que escapan de la orquesta con su manifiesto deseo de vivir, porque la impresión recibida es tan poco estruendosa como la que producen otros bailes de la reina de los crótalos.

No despierta en nosotros la música cálida de Valverde interjecciones, "olés" y "vivas", ni menos aún nos desborda el sensualismo y el deseo, porque aquí también, como en todas las danzas de la "Argentina", hay una armonía apacible que hace pensar y hace sentir siempre en silencio, devota y sencillamente....

\section{Úlima visita}

La última visita de Antonia Mercé "La Argentina" a México fue en 1934. Actuó en el ciclo de festividades relativas a la inauguración del Palacio de Bellas Artes (27 de septiembre). 
En el gran escenario se presentó entre el 3 y el 13 de noviembre. Su amplio repertorio le permitió satisfacer los variados gustos del público. Las piezas ofrecidas durante la temporada fueron: La andaluza sentimental (música de Joaquín Turina), La vida breve (Manuel de Falla), Rondena (Isaac Albéniz), Seguidillas (sin música), Tango flamenco (Ballesteros-Romero), Lagarterana (J. Guerrero), Canción de cuna, Córdoba (Albéniz), Jota aragonesa (De Falla), Rapsodia vasca (J. M. Usandizaga), Cuba (Albéniz), Danza $V$ (Enrique Granados), Jota valenciana (Granados), La corrida (Valverde), Evocación (Albéniz), Danza de gitana (Halffter), Danza del terror (De Falla), Arriero por la carretera de Sevilla (Manuel Infante), Puerta de tierra (Albéniz), Dolor (P. Donostia), Goyescas (Granados), Danza ibérica (Joaquín Nin y Castellanos) — se trató de un drama coreográfico en tres partes sin interrupción-, Navarra (Albéniz), La cariñosa (danza popular de las islas Filipinas), Canción y danza (F. Mompou), Serenata (J. Malats), Danza del miedo (De Falla), Andaluza (De Falla), Oriental (Albéniz), Goyescas (Granados), Corpus de Sevilla (Albéniz), Canción del pastor joven (Donostia), Danza de los ojos (Granados), Malagueña (Albéniz), Danza del fuego (De Falla). Todas las coreografías habían sido diseñadas por la bailarina; el vestuario, según indicaban los programas de mano, era de Mademoiselle Alix. ${ }^{21}$

Tan dilatado y vasto repertorio dejó boquiabiertos a sus fanáticos admiradores, toda vez que el arte de la danza, en el espectáculo de "La Argentina", se concentraba en su figura. Carlos González Peña nos indica con detalle cómo se realizaba el fogonazo de su aparición:

No puede ser más sencillo el recinto en que actúa Una enorme y lisa cortina, de color uniforme, rodeando el tablado A la izquierda, un piano de cola. Ha desaparecido la orquesta. Deseosa, acaso, de simplificar y simplificar aún más, Antonia Mercé acude a la pauta pianística para dibujar, con firme escorzo, pasos y actitudes. Música española fluyendo del teclado. Luz, a tono con la emoción que se trate de despertar. Una figura, bellos trajes... No habrá más y con eso basta .... Grande es la artista; lo llenará todo, creando plástica y rítmicamente un mundo. ${ }^{22}$

En el escenario del nuevo Palacio se comprobaba el arte de esta gran artista, ahora ya reconocido como un arte universal y maduro. Á los "conocedores" no les sorprendió la facilidad con la que Antonia Mercé se "echó al público a la bolsa", corroborando con la vista lo que ya se sabía de ella:

\footnotetext{
21 50ad, 300-301.
${ }^{22}$ AM, 119-120.
} 
El baile es todo para mí. Muy a menudo se ha dicho que había nacido bailando. Es verdad, puesto que mi madre era bailarina. No es de extrañarse, entonces, del amor profundo que tengo por este arte que es mi vida, la esencia más íntima de mi ser. ${ }^{23}$

Y por las reacciones de González Peña podrá entenderse hoy que el fenómeno que acaecía en el foro de Bellas Artes no era cualquier cosa, toda vez que un espectador común y corriente, aun sin la información de la fama y las cualidades de Antonia, podía descubrir, sentir y compartir el gran momento dancístico.

A diferencia de los falsos intérpretes, olvidados, los más,.... Antonia Mercé no se reduce a mimar echándola de trascendental con porción de gestos y movimientos enigmáticos, cuando no estrafalarios. Antonia Mercé baila. Baila siempre. Indefinidamente baila. El baile se asocia con el gesto. Compenétranse ambos. Se funden; son, complementariamente, una misma creación. iY las castañuelas hablan! ${ }^{24}$

Y con el mismo entusiasmo, califica González Peña, algunas de las interpretaciones mencionando los títulos de las piezas, toda vez que para él, como crítico - y para Noverre, a quien cita-, "la danza en acción es el órgano que debe transmitir y explicar claramente las ideas escritas de la música":

Estados de ánimo, tipos, escenas, se reflejarán en el baile: gracia estremecida en la danza de La vida breve De Falla; misterio hierático en la del Fuego, de El amor brujo; alegría, en el Tango flamenco; bobalicona ingenuidad en Lagarterana; ímpetu popularesco en la Jota aragonesa; doble elegancia con amoroso dejo en la maravillosa quinta Danza de Granados; señorío en la Córdoba, de Albéniz. Tal es, en suma, la intensidad del baile de "La Argentina", que ocasión hay en que no se necesite de la música, y por sí misma se baste para crearla, como en las Seguidillas; y tan grandes su riqueza e intención plásticas, que nos dé, estilizada, una sîntesis de la fiesta taurina en $L a$ corrida... [como también] aquellas antiguas, inolvidables y ahora condensadas Alegrías de Valverde. ${ }^{25}$

Y era la danza de "La Argentina" la que atraía y arrobaba, a diferencia de la fama que otras bailarinas --buenas y malas-- adquirían por motivos extra-dancísticos. El público de 1934 recordaba poco de sus visitas anteriores toda vez que en 1917 y 1920 la situación revolucionaria todavía no permitía una afluencia uniforme, constante de espectadores -fenómeno

\footnotetext{
${ }^{23} R R, 2$ de febrero de 1936

$24 A M, 119-120$

$25 A M, 121$.
} 
que vendría a hacerse realidad en el Palacio de Bellas Artes, precisamente a partir de 1934 -; además, pocos habían sido los preparativos publicitarios para recibir a Antonia Mercé. En una apresurada y superficial entrevista realizada en París por Francisco Melgar, ${ }^{26}$ la bailarina sólo había contestado generalidades, excepto en lo referente a su trabajo y su adiestramiento:

Mi vida bien pronto está descrita: una sola palabra la llena: trabajo. Trabajo todo el día y por la noche descanso para reanudar al día siguiente con más ardor, si cabe, las tareas de la víspera. Porque tengo yo esta suerte, que, mientras más adentro penetro en mi arte, más me entusiasmo y mayores son mis deseos de perfeccionarme.

$\mathrm{Y}$ a la pregunta-exclamación del periodista, en torno a que debería ya considerarse en la cima, en la meta, responde Antonia:

iNo; qué esperanza! Si yo quisiera vivir cien años y estar joven y fuerte y ágil, para realizar todas las ideas que bullen aquí dentro.

Es Roberto "El Diablo" quien, ya en plenas funciones en Bellas Artes, la obliga a comentar sus impresiones en torno a sus anteriores visitas. Dentro de la charla normal, "La Argentina" revela:

Cómo no recordar con efusión aquellas noches de mis primeros triunfos aquí, que tanto me alentaron en los albores de mi carrera ar tística. iQué lastima que ya no exista el Teatro Colón! La otra tarde me fui sola, caminado a pie, para pasar siquiera frente de su fachada, en un silencioso homenaje... ${ }^{27}$

Recordaba años anteriores. Las imágenes no habían cambiado en su cabeza y, por lo visto, ella misma no había cambiado. De acuerdo a las acotaciones de Roberto "El Diablo"

Es la misma de ayer. ¿Por qué prodigio se habrá inmovilizado el tiempo bajo su leve planta? Tornando a contemplarla tras ausencia tan larga, con la misma silueta grácil de antaño y su antigua jovialidad en el rostro, nos imaginamos de pronto que hay una equivocación en las cifras del calendario y que en lugar de marcar 1934 debieran señalar 1920. Fuera de la voz que se le ha velado un poco, todo en ella se conserva igual que cuando nos visitara la última vez. Es la misma de ayer... ${ }^{28}$

${ }_{27}^{26} R R, 30$ de septiembre de 1934 .

${ }^{27} \mathrm{CCU}, 84$,

${ }^{28} \mathrm{CCU}, 83$. 
Murió repentinamente en su villa, Miraflores, cerca de Bayonne, Francia, el 18 de julio de 1936. Día y año significativos, también por otras razones, para España. El arte de Antonia Mercé no sólo construyó una memoria dancística sino un renacimiento de ese amplio, terrible, a veces perfecto universo que llamamos danza española. Apenas dos meses después de la muerte de "La Argentina", nuestro Carlos Pellicer lloraba un poema: "Lutos por Antonia Mercé", que decía:

\section{LUTOS POR ANTONIA MERCÉ}

Por los toreros y las bailarinas

esta voz de palmeras y marinas

ladea su esbeltez, sus arcos vivos.

Y este baile sombrio

y este rio en penumbra,

con poca lluvia y pájaros heridos

pisa apenas la arena de su lecho de muerte

repasando humedades en silencio.

A la cortina escóndela, más plegada que nunca, teatro al mediodía morado de recuerdos;

yo guardaré mis manos como guantes vacíos;

no seré el palomar de todos los aplausos.

Andaré con la brisa

de baile en baile preguntando, ¿dónde

podrá la brisa estar, que haya otra brisa

que tan de prisa y a mi voz se esconde?

¿Dónde estará la risa

de sus manos maderas en jolgorio, las urnas claras de gentil emporio, armas, trofeos de ligera liza?

Como una niña huérfana la brisa tendrá en sus manos las fores descalzas del patio abandonado. Y en las lozas sin música la huella de un pie muerto arrastrado entre encajes.

Yo palpo las cinturas y en todas dura la ineptitud de un pobre barro seco. Este fuego de julio descendió tan a fondo que la raíz del ritmo se extrae con dos dedos. 
Y serán los roperos como ataúdes donde los trajes, tiesos, sabiéndolo, se pudran; después, en un museo, las viudas multitudes dirán con suave gozo su tristeza insepulta.

Por sangres diferentes fuiste sonora, como España es distinta y es sólo una.

La brisa acendra rosas bajo la luna.

Como en ninguna noche hay luna ahora.

Tras el tacón de tu calzado esbelto

fueron mis ojos álgebra y senda mis oídos;

la justicia del número que enigmas ha resuelto

y camino dificil a todos los olvidos.

Luna como ninguna la luna está.

Por los toreros y las bailarinas

-estatuas en banderillas y pies primeros-

luna como ninguna la luna está.

Y esta voz de palmeras y marinas

y este baile sombrio

y este río penumbra

con poca lluvia y pájaros heridos

piso apenas la arena de su lecho de muerte,

repasando humedades en silencio. ${ }^{29}$

La muerte de Antonia Mercé impresionó grandemente a los cronistas de teatro y de danza. La recordaban viva y gratamente en sus actuaciones durante la inauguración del Palacio de Bellas Artes. En su "Laude por 'La Argentina", Roberto "El Diablo" afirma:

Repasad mentalmente los nombres de todas las otras ilustres sacerdotisas de Terpsícore y no encontraréis ninguno que resista el parangón frente al de "La Argentina". Por eso era ella la única que iba y venía por los cuatro puntos cardinales del orbe como armoniosa mensajera del alígero encanto de la danza ${ }^{30}$

Al referirse a la significativa circunstancia de haber recibido la Ciudad

${ }^{29} R R, 23$ de agosto de 1936. En Recinto y otras imágenes (1941) el poema está dedicado a Manuel M. Ponce (Cf: Obras, Poesía, Fondo de Cultura Económica, 1981).

${ }^{30} R R, 26$ de julio de 1936 . 
de México la visita de Antonia Mercé en los inicios de su carrera y, más tarde, en la plenitud de su obra y de su arte, el periodista afirma:

Tuvimos nosotros la rara fortuna de admirarlo [su arte] en el alfa y el omega de su personalidad insigne. Cuando todavía su nombre no estaba crismado por la consagración universal, llegó por primera vez al desaparecido escenario del Teatro Colón y la revelación de sus bailes estilizados fue para nuestros ojos y nuestros espíritus como un deslumbramiento. Acostumbrados a las bailarinas de la España de pandereta, eso de contemplar" los aires regionales de Andalucía y de Castilla a base de ritmos depurados, revestidos de exquisitez y elegancia, sin que, por otra parte, perdieran su esencia original, nos pareció de pronto fruto de milagro.

Y acierta en lo que respecta a la relación que misteriosa o sencillamente, de manera orgánica, se establece entre el gran bailarín y los espectadores carentes de información con respecto al género o las piezas que interpreta. El cronista ponía el dedo en la llaga del procedimiento, directo y sin cortapisas, que los públicos amplios, auténticamente emotivos, aplican para "captar" las calidades de un gran artista.

La ciudad entera, que entonces por cruenta contienda fraticida estaba sedienta de espectáculos bellos, dio rendidamente su admiración, estableciéndose entre la artista y el público esa misteriosa corriente anímica que sólo alcanzan los privilegiados de la gloria.

Y, al fin, Roberto "El Diablo" se despedía de Antonia, colocándola en el lugar más alto de la escala de la fama, gracias a un talento excepcional que "La Argentina" supo conservar a lo largo de una carrera auténticamente pura, de un arte que habría de alcanzar para la danza española la dimensión de "modalidad o estilo" independiente:

Como su hermana en Apolo, la Pávlova, ha muerto Antonia Mercé en la hora de los elegidos de los dioses: cuando el triunfo y la fortuna se mantenían fieles en su umbral iOtra nueva estrella se ha incrustado en el cielo de la inmortalidad!

\section{SİGLAS}

AM Carlos González Peña: El alma y la máscara, Editorial Stylo, México, 1948. $283 \mathrm{pp}$.

CCU Roberto "El Diablo": Cincuenta Close-ups, Ediciones Botas, 1935. $260 \mathrm{pp}$. 
$50 a d 50$ años de danza. Palacio de Bellas Artes, INBA-SEP, 1986. 2 tomos. $664 \mathrm{pp}$.

Cuad Octavio Paz: Cuadrivio, Joaquín Mortiz, México, 3a. ed., 1972. $205 \mathrm{pp}$.

DAN Lincoln Kirstein: Dance A short history of classic theatrical dancing, A Dance Horizons Republication, New York, 1969. 400 pp.

DE Anatole Chujoy (comp.): The Dance Encyclopedia, Barnes and Co., New York, 1949, 546 pp.

DTA Selma Jeanne Cohen (ed.): Dance as a theatre art, Dodd, Mead and Co., New York, 1975, 224 pp.

EX Excélsior

FVM Fernando Quiñones: El flamenco vida y muerte, Plaza \& Janés, Barcelona, 1971.270 pp.

NPD Paul Magriel (ed.): Nijinsky, Pávlova, Duncan, Da Cappo Press, 1977. $81+78+85$ pp.

Pe Pegaso, revista semanal, 1917. Edición facsimilar del Fondo de Cultura Económica, 1979. 365 pp.

RR Revista de Revistas 